\title{
Analysis of Student Admission Methods of Two Industrial Product Design Departments in Turkey and Innovation Capabilities: A Conceptual Framework
}

\author{
Ilgım EROĞLU*
}

Abstract

Until recently, there had been two diversified student admission methods for industrial product design departments in Turkey. These models can be shortly defined as aptitude tests and central examinations conducted by Measuring, Selection and Placement Center (Ölçme Seçme ve Yerleştirme Merkezi - ÖSYM). The nature of these admission methods provided universities with students who had both different abilities and backgrounds. In this study, a conceptual framework is provided to discuss if these differences can enable design students' with different approaches to design-driven innovation. Innovation capabilities for different types of design-driven innovation are identified through related studies in literature to be evaluated together with requirements for success in the two different admission methods.

Keywords: Design education, design-driven innovation, radical innovation, incremental innovation

Özet

Yakın zamana kadar, Türkiye'de endüstri ürünleri tasarımı departmanları için iki çeşit öğrenci kabul yöntemi geçerli olmuştur. Bu modeller kısaca, Ölçme, Seçme ve Yerleştirme Merkezi (ÖSYM) tarafından yapılan merkezi sınavlar ve üniversiteler tarafından yapılan özel yetenek sınavları olarak tanımlanabilir. Bu kabul yöntemlerinin doğası, farklı yetenekleri ve geçmişleri olan öğrencilerin üniversitelerde eğitim görmesini sağlamıştır. Bu çalışmada, bu farklılıkların tasarım öğrencilerinin tasarım odaklı yenileşim yaklaşımlarında farklılaşma yaratıp yaratmayacağının tartışılması için kavramsal bir çerçeve sunulmuştur. Farklı tipte tasarım odaklı yenileşimler için inovasyon kabiliyetleri, iki farklı kabul yöntemindeki başarı şartlarıyla birlikte değerlendirilmek üzere, literatürdeki ilgili çalışmalarla belirlenmiştir.

Anahtar Kelimeler: Tasarım eğitimi, tasarım odaklı yenileşim, radikal yenileşim, artımlı yenileşim 


\section{Introduction}

Recently, innovations in products is discussed by using both design and technology aspects. This relatively new approach emphasizes the importance of design for innovation and novelty in products. Since different types of design driven- innovations require diverse design skills, it may be important to examine skill developments in design education.

The aim of this study is to discuss if outcomes of different student application methods can lead to differentiation on basic functional capabilities of industrial product designers in Turkey. The diversity of graduates is discussed based on the types of innovation they may tend to produce, together with their ability to generate different types of design-driven innovations. A conceptual framework is provided in order to discuss possible differentiations, which can be researched further in upcoming studies.

\section{A review of required capabilities for design-driven innovation types}

In his study on design-driven innovation, Verganti (2009) concentrated on meaning and technology; where meaning is the core aspect for generating innovation through application of design capabilities. There are also studies that aim to identify capabilities that lead to design-driven radical innovation and design-driven incremental innovation as outcomes of design activities (Franke, Von Hippel \& Schreier, 2006; Urban and Von Hippel, 1988; Dell'Era and Verganti, 2009-a,b).

Since different types of innovations require different capabilities, the reflection of these capabilities to designers on personal levels may also been studied. Even though most of the above mentioned studies examine the development of the capability that is necessary for design management practices, designers also seem to have solely functional roles in some companies, apart from being team members (Perks, Cooper \& Jones, 2005). Therefore, possible designer approaches to a design solution and their probable outcomes can be discussed based on their functional capabilities.

The differentiation of factors that lead to incremental or radical innovation can be discussed in roughly two major titles: diversity of information sources and application of analogies.

Before discussing the differences between designer ca- pabilities, a basic definition of the approach to the contribution of design to innovation can be useful. It is stated that, one of the main points that differentiate design-driven innovation from technology-driven innovation is its implementation of interpretation and envisioning in the process (Verganti and Öberg, 2013). As mentioned before, design-driven innovation differentiates itself from technology -driven innovation by focusing on product meanings rather than technicality (Verganti, 2009). This tendency is reflected also in the choice of innovation sources, as hermeneutic capabilities are said to have great importance in design-driven innovation (Verganti, 2011). On the meaning basis, radical innovations refer to drastic changes in product meanings, while incremental innovations seek the best application of the new meaning through relatively minor improvements (Norman and Verganti, 2014). The two groups for differentiation factors mentioned above are evaluated through this perspective.

Diversity of information sources, which are studied through researchers and designers in most of the cases, are claimed to be crucial for the generation of design-driven radical innovation (Dell'Era, Marchesi \& Verganti, 2008).

One of the main studies in design field that identify diversity in design teams of radical innovators is conducted by Dell'Era and Verganti (2010). Results of their study suggest that radical innovators (1) have their products designed mostly by outsourced designers, (2) employ more outsourced designers to work in their in-house design projects, (3) employ more foreign designers when compared to incremental innovators, (4) employ more designers with diverse backgrounds, (5) have a tendency to employ designers from subsectors. Another example for a study on design field is conducted by Perks et. al. (2005); according to the study, external designers are commonly seen in radical product developers, while incremental innovators mostly conduct design projects with their internal designers. Their findings are also supported by some of the studies that explore creativity in behavioural sciences. Amabile and Pratt (2016) state that, skills in several domains may be required to build novelty in ideas. Also, multidisciplinary work teams formed with employees of diversified backgrounds with different qualitative abilities are claimed as being facilitators of creativity (Woodman, Sawyer \& Griffin, 1993; Basadur, 2004). Within a general comparison of radical and incremental capabilities, sans differentiation through technology or design drive, there are some studies which 
mention building effective relationships with external sources enforce radical innovation, while internal relationship quality generates incremental innovation capability (Forés and Camisón, 2016; Obal, Kannan Narasimhan \& Ko, 2016).

Another factor that affects innovation outcomes is field expertise. Field expertise can be regarded as one outcome of lack of diversity; however it points to a more individualistic aspect, therefore can be related to more cognitive factors in design, such as design fixation. Design fixation refers to a tendency to produce derivations of exising solutions to a design problem, while looking for an alternative solution to the same problem (Jansson and Smith, 1991; Crilly, 2015). Incremental innovators may have a tendency to be affected by design fixation, disabling them to produce radical innovations. Field expertise is claimed to be a facilitator of design fixation (Purcell, Williams, Gero \& Colbron, 1993) and it can be said that it is more possible to avoid design fixation that arise from field expertise in multidisciplinary teams. Again, this idea is backed up by studies conducted on behavioural sciences, pointing out that field independence can enhance creativity (Woodman, 1993; Linsey, Tseng, Fu, Cagan, Wood \& Schunn, 2010; Viswanathan and Linsey, 2012). It can be roughly said that field expertise on team or individual level can create monotony through application of a multidisciplinary view, leading to reduction of radical innovation capabilities.

The second aspect regarding the differences between incremental and radical innovation can be named as the application of analogies. It is stated that, inspecting areas like fashion and art in an attempt to transfer meanings and visual cues enhances radical innovation capabilities (Dell'Era and Verganti, 2009-b). Also, international designers, who function as language brokers, can also enhance radical innovation (Dell'Era and Verganti, 2009-a). The major force for creating a novelty here can be claimed to bring unusual meaning generators from relatively unconventional sources. This tendency is also mentioned in studies ondesign fixation as the use of analogies. It is claimed that it can be useful to look for analogical solutions from other fields in order to break replication of conventional solutions (Linsey et. al., 2010; Dahl and Moreau, 2002). It is stressed that employing evolved analogies aid defixation; designers may employ solutions from different problem areas to bring a novel solution for the actual problem (Smith, Linsey \& Kerne, 2011). Wisvanathan and Linsey (2012) also claim that such defixation sources mostly help designers that are hampered by design expertise overcome fixation. It should be also noted that, while analogies from other fields avoid fixation, analogies that are claimed to be "within domain" lead to fixation (Dahl and Moreau, 2002). Within domain analogies can come from market researches which require benchmarking through existing products. And market research is also mentioned to be a facilitator of incremental innovation capabilities (Norman and Verganti, 2014).

\section{The profile of industrial product design students in Turkey}

When the admission methods of different universities are considered, it can be seen that two main methods for student election was considered to start the $f$ industrial design programs at Middle East Technical University (METU) and Mimar Sinan Fine Arts University (MSFAU).

The first industrial product design department was found in MSFAU, at the time being Istanbul State Fine Arts Academy (İstanbul Devlet Güzel Sanatlar Akademisi - IDGSA). It is stated that building an undergraduate program for a profession that included the word "industry" in its name became controversial in a fine arts academy (Küçükerman, 2006). However, there had formerly been institutions which aimed to bring the worlds of art and industry together. One of the previous institutions which lead to the formation of İDGSA was "Sanayi-i Nefise Mektebi", which can be roughly translated as "School of Fine Industry” (Küçükerman, 2006). Also, one of the earlier practices of industrial design was at "Tatbiki Güzel Sanatlar Okulu (Applied Fine Arts School)", which continued its practices under Marmara University later on (Celbiş, 2006). Therefore, it can be said that earlier examples of industrial product design practice at academic level took place in institutions that had close relations with fine arts.

The second independent industrial product design program was established in METU, in 1979 (Asatekin, 2006). Initial students were selected among the candidates who had become successful in preparation programs; also it was strongly argued that industrial product design students should be placed in architecture faculties (Asatekin, 2006). Although in the beginning it elected students through aptitude tests, Istanbul Technical University (ITU) Industrial Product Design Department also converted to ÖSYM exams; this may not be surprising as fundamental aims of the department were in line with METU Industrial Product Design Department (Bayazıt, 2006). 
In Turkey, as of 2018, all industrial design programs accept students through MF4 (MF being abbreviation for "mathematics - science") examination scores, although aptitude tests were conducted until 2016 (ÖSYM, 2017-a). When examples for questions that are asked within MF4 score evaluation are studied, it can be seen that questions about mathematics and physics require analytical problem solving skills (ÖSYM, 2018-b). It is required from students to identify the necessary data to solve the problem and apply them to the formula or logic that is suitable for the solution.

During the foundation of METU Industrial Design department, it was forecasted that the first couple of semesters of the education would intensively include "knowledge" and "communication" courses. Asatekin (2006) defines knowledge courses as "physics, material, psychology, etc." and communication courses as "model making, drawing, etc.". Traces of this tendency can also be seen in the graduate program of ITU, one of the oldest representatives of MF4 admission (ITU, 2018). Mathematics and physics subjects can be seen within mandatory courses of the first year. Inclusion of both communication and knowledge courses within the first years of education may be interpreted as a transition to visual expression skills, while providing the analytical skills with the help of students' relatively fresh high school knowledge.

Aptitude tests are conducted by universities and the scores that define the list of students that are eligible for enrolment are defined by a formula that is described in ÖSYM guide (ÖSYM, 2017-b). The aptitude tests in the schools are done through several stages. The first stage is a general qualification exam (MU, 2017; MSFAU, 2017-a). This exam is done on a broad level by members of most departments, which form the jury, to elect students who have basic drawing skills. Questions can include human figures that are generally pictured while conducting some tasks. After initial elimination, departments apply their own aptitude tests, focusing on the requirements off their departments (MU, 2017; MSFAU, 2017-a). The questions asked in the department aptitude tests could include drawings of products from several angles, hands and arms using a product or drawings of objects within a described state. Industrial product design departments of referred universities elected students through this process until 2017.

When the curricula of universities with aptitude test backgrounds are evaluated, it can be seen that the first couple of semesters are concentrated on basic visual communication skills, which are again in line with students' backgrounds (MSFAU, 2017-b; MU, 2012). Unlike METU or ITU, MSFAU and MU do not include physics or mathematics as mandatory courses (METU, 2017; MU, 2012; MSFAU, 2017-b).

As a result, it can be said that in the first two or three semesters of their education students continue with the skills which brought them to universities and take courses that focus on industrial design activity later in their educations. So while they are brought to their departments with differentiated abilities, this differentiation on educational activities also continues for several semesters.

\section{Possible differences in capabilities of industrial product design students}

Dedicated preparation of students for graduate program entries constitutes at least the last two years of their high school education. Students get highly involved with the practices that will get them elected to their choice of departments. Students mostly do not prepare themselves for both of the exams and they only study for one of them (Ekmekçioğlu, 2012). Several years' preparations, combined with junior years that are in line with students' backgrounds, can affect the way that students' approach to design problems, since intelligence is claimed to be affected by one's habits of mind (Resnick, 2001; D'zurilla and Goldfried, 1971). There are studies which claim that multi dimensional spatial abilities are related with each other, however they are not related to mathematical abilities (Ho, Eastman and Catrambone, 2006); therefore possible differences in students' abilities is studied in this section.

As mentioned above, the questions which students deal in order to gain high MF4 scores require logical reasoning, along with data gathering abilities. It is also stated that students with mathematical problem solving abilities “...are analytical, both in thinking issues through themselves and in examining the arguments put forth by others" (Schoenfeld, 1992). Schoenfeld (1992) also claims that mathematical thinkers can apply their skills to visualization by applying proportional reasoning to scale models. Lesh claims that mathematics;

“... involves interpreting situations mathematically; it involves mathematizing (e.g., quantifying, visualizing, di- 
mensionalizing, or coordinatizing) structurally interesting systems; and, it involves the using and interpreting an ever-expanding array of specialized languages, symbols, graphs, graphics, concrete models, or other representational media for purposes that range from construction, to description, or explanation" (Lesh, 2000:sayfa numarası eklenmeli).

One aspect that may be important in Lesh's (2000) study is that, in a daily-life problem solving process, where mathematical skills are applied, problem solving starts with identifying the "givens" in the environment. There also studies hinting that visualization may improve mathematical understanding. Edens and Potter (2007) compared the success of students, who visualized mathematical questions in their stud,y to conclude that students, who demonstrate a more proper an proportional description of the problem, showed more success in solving the problem. Students' spatial abilities seem to be related with their mathematical abilities, and it is discussed that art classes can both improve artistic and mathematical ability (Edens and Potter, 2007). Studies that focus on visuo-spatial working memory, which is related to storage and assessment of visual and spatial information on short term, is found to be linked with mathematical abilities (Alloway and Passolunghi, 2011; Reuhkala, 2001). Therefore, it may also be assumed that success in mathematics can be an indicator of a potential special ability. Students with mathematical abilities are also said to have a more developed working memory, which basically represents the capacity to store and process data during a cognitive activity (Holmes and Adams, 2006).

The way visual arts students formulate problems and solve problems may differ from others with scientific backgrounds. On their study on brain activities related to drawing, Frith and Law (1995) claim that in order to draw, several different parts of the brain are activated in order to comply with the description and placements in the drawing. Also, it is stated that the same part of the brain is used for viewing and imagining scenes (Frith and Law, 1995). Apart from the studies mentioned above, Nelson, Martin and Baldwin (1998) also studied a relation between scientific abilities and drawing skills. Although conducted on young children, their research had a significant outcome stressing that visualization abilities and children's ability to define materials of objects were correlated; the correlation can be said to be in line with the finding that imagination and viewing take place in the same area of the brain. This result can be interpreted as better drawing skills lead to better detail identification of surfaces. Grossman (1970) study also stresses that children's visual analyzing capacity is correlated with their visual representation skills. It is also claimed that problem solving habits of artists have a resemblance to scientific researches. Caves (2002) states that in both of these activities a new discovery to create values are sought together with a strategy to apply them; however visual artists' formulation of problems and solutions are internal. Thus, the problems encountered by artists are not always precise. Therefore, visual arts students are described as “...being serious and introspective, socially reserved, relatively indifferent to accepted standards of behaviour and morality, imaginative and unconventional in outlook, intensely subjective and highly self-sufficient", separating them from others (Caves 2000). Some studies also mention thate cognitive transition from problem solving to problem finding is a common problem that is seen among visual arts students. As arts students form compositions or choreographies that follow a problem given by their instructor, all they have to do is to find a solution to that very specific problem, on the other hand, in order to reach success in a creative thinking process, they should also formulate the problem which is expected to be solved (Gibbons 2007).

One of the main aspects that may be discussed while comparing students with differing backgrounds can be their choice of sketching mediums. While students with artistic backgrounds can be expected to sketch with conventional instruments such as paper and pen, others may feel more comfortable with computer programs, as they may find it difficult to develop adequate hand sketching abilities during their university education. Won (2001) compared two different mediums for sketching, and concluded that in both situations designers first formed a solution in their minds, and then transferred the solutions to the mediums. While doing so, they frequently go between "seeing" the whole to concentrate on a detail to "seeing (it) as" something separate. While the way a designer prefers to sketch does not drastically change the way designer thinks, it was observed that sketching with computers makes the transition from working on details to the total more frequent and effective (Von, 2001).

It can be said that while visual abilities and mathematical capabilities seem to enhance each other at least to a level, 
the tendencies of problem solving may create a difference among students with differing backgrounds.

\section{The discussion of effects of backgrounds on approach to innovation}

As mentioned above, the core factors, which differentiate innovative capacities on cognitive level, are application of analogies and derivation of information from multiple disciplines. Another cognitive force that has an effect on both of these factors can be said to be design fixation, as it can enable or disable their the occurrence.

Students with mathematical abilities are said to have developed working memories, both on general level and visuospatial level. Students with mathematical abilities are able to remember and process visual data in short time. Smith et. al. (2011) claim that occurrence of evolved analogies can be a result of coincidental discoveries, since they may come from areas which are quite distant from the original problem area. Therefore, ability to process visuo-spatial data on short time may help to the application of analogies, which are derived from areas that are not consciously defined as areas for probable solutions by designers. An increase in the possibility to generate an analogy from other domains will enable students to come up with radical solutions for design problems.

Another tendency of students with science education background can be said to be searching valid data from the environment to solve a problem. This tendency may help both innovation types; it can lead students to derive data from existing problem area and it can also help them take a problem on broader level to avoid working through existing solutions. Verganti (2009) states that, talking with users of products that are available on the market would not lead designers to original solutions, since the knowledge and experiences of users are restricted with limits of current product concepts. In an effort to start with a logical base to a design problem, students with scientific background may talk with ordinary users to address problem areas. This tendency, by definition, can lead them to human-centred design, which is stated as a facilitator of incremental innovation (Norman and Verganti, 2014). Human-centered design may lead students to stay within domain, therefore apply within domain analogies. On the other hand, as they are accustomed to deal with problem areas that are not purely visual on artistic level, they may have a more interdisciplinary approach to a design problem, which would lead to enhancement of radical innovation occurrence.

The statement that viewing and imagination takes place in the same part of the brain may suggest that students with artistic capabilities have a developed viewing ability. Also, their visual analyzing capabilities are developed, which can lead to a better understanding of visual details. As it is also mentioned, children with better drawing abilities have a better understanding of materials. Hence it can be claimed that students with artistic abilities could have a better understanding about visual details.

A better understanding of visual details may help transferring visual codes within domains. Students with artistic backgrounds can be able to identify visual codes with more details; therefore there can be a greater chance for them to act as "language brokers" between industries (Verganti, 2008). As a result, their ability to identify visual details may help them generate radical innovations in product meanings.

On the other hand, their ability to define and revive visual elements with accuracy on broader term may lead to design fixation, therefore it may diminish their capacity to generate radical innovations while enhancing incremental innovations. Cheng, Mugge and Schoormans (2014) state that industrial design students have a tendency to get fixated on problem solutions on visual basis, when they are shown the complete image of the solution; however showing partial images can enhance their creativity. This disposition may be greater within students who have artistic backgrounds, as their abilities to identify visual details are developed.

Industrial product design students with artistic backgrounds have a habit of bringing out solutions to defined problems, based on their visual abilities. However, their lack of practice in defining a problem may lead them to work within already defined design problems. This possible tendency may lead them to work within incremental innovations; which are basically more developed versions of existing solutions.

A model that summarizes the discussions above can be seen at Figure 1 below. 


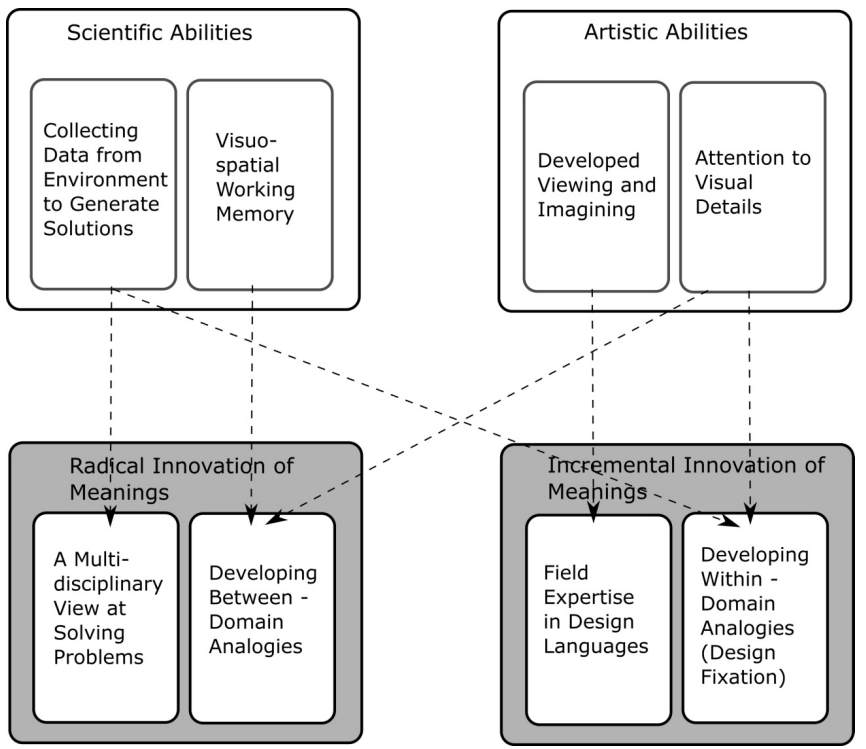

Figure 1. Conceptual model to discuss students' abilities

\section{Discussions}

This study aims to evaluate the possibility of contribution of industrial design students with varying backgrounds to different innovation types to fill the gap in the literature about comparison of different student types in design practice. Even though the conceptual frameworks study is conducted by using the literature and therefore is limited at this stage, it can be thought that capabilities of students to enhance innovative capabilities may differ depending on their backgrounds.

As a result of a preliminary evaluation, it can be said that both admission methods support each kind of design-driven innovation; however, they support in different ways. Students with mathematical abilities may apply their tendency to derie data from the environment for both radical and incremental innovations. The Ssame applies to students with artistic backgrounds and their ability to pay attention to visual details. Both abilities can be used to create within-domain analogies to support incremental innovations. The ability to pay attention to details may also support between-domain analogies, if language brokering is done through other fields such as art and fashion. Likely, deriving data from environment may built up a tendency to provide an interdisciplinary point of view to the students with scientific backgrounds, as they already have fundamentals based on subjects that are not purely visual. Having a developed visuo-spatial working memory or developed viewing and imagining ability can create a differentiation between students, as former supports radical innovation through rapid identification of between-domain analogies and later can support incremental innovation abilities as it may enhance field expertise.

Although the conceptual framework is based on basic literature that is available, the subject can be developed further to identify more differences between students with varying backgrounds. Industrial product design is also studied within different disciplines that focus on engineering and arts in other countries; therefore the necessity of different student types in industrial product design is worth discussion in order to enforce both innovation types in design practice. Even though there is now a unity about election of students, former students can be reached to conduct more in dept studies to analyze the topic.

\section{References}

Alloway, T. P., and Passolunghi, M. C. (2011). "The relationship between working memory, IQ, and mathematical skills in children". Learning and Individual Differences, 21(1), 133137.

Amabile, T. M., and Pratt, M. G. (2016). "The Dynamic Componential Model of Creativity and Innovation in Organizations: Making Progress, Making Meaning”. Research in Organizational Behavior, 36, 157-183.

Asatekin, M. (2006). “ODTü Mimarlık Fakültesi Endüstri Ürünleri Tasarımı Bölümü "BAŞLANGIÇ NOTLARI”". Tasarım+ Kuram, 3(5), 28-33.

Basadur, M. (2004). "Leading Others to Think Innovatively Together: Creative Leadership." The Leadership Quarterly 15.1, 103--21.

Bayazıt, N. (2006). “İTü’de Endüstri Ürünleri Tasarımı Bölümü “DENEYİ'mim". Tasarım+ Kuram, 3(5), 41-53.

Caves, R. E. (2000). Creative industries: Contracts between art and commerce (No. 20). Harvard University Press.

Celbiş, ü. (2006). "Marmara Üniversitesi, Güzel Sanatlar Fakültesi, Endüstri Ürünleri Tasarımı Bölümü”. Tasarım+Kuram, 3(5), 34-40.

Cheng, P., Mugge, R., \& Schoormans, J. P. (2014). “A new strategy to reduce design fixation: Presenting partial photographs to designers". Design Studies, 35(4), 374-391.

Crilly, N. (2015). "Fixation and Creativity in Concept Development: The Attitudes and Practices of Expert Designers". Design Studies, 38, 54-91.

Dahl, D. W., and Moreau, P. (2002). "The influence and value of analogical thinking during new product ideation". Journal of Marketing Research, 39(1), 47-60. 
Dell’Era, C., Marchesi, A., and Verganti, R. (2008). “Linguistic Network Configurations: Management of Innovation in Design-Intensive Firms". International Journal of Innovation Management, 12(01), 1-19.

Dell'Era, C., and Verganti, R. (2009 - a). “The Impact of International Designers on Firm Innovation Capability and Consumer Interest". International Journal of Operations \& Production Management, 29(9), 870-893.

Dell'Era, C., and Verganti, R. (2009 - b). “Design-Driven Laboratories: Organization and Strategy of Laboratories Specialized in The Development of Radical DesignDriven Innovations". R\&D Management, 39(1), 1-20.

Dell'Era, C., and Verganti, R. (2010). “Collaborative Strategies in Design-Intensive Industries: Knowledge Diversity and Innovation”. Long Range Planning, 43(1), 123-141.

D’zurilla, T. J., and Goldfried, M. R. (1971). “Problem solving and behavior modification". Journal of Abnormal Psychology, 78(1), 107.

Edens, K., and Potter, E. (2007). "The relationship of drawing and mathematical problem solving: Draw for math tasks." Studies in Art Education, 48(3), 282-298.

Ekmekçioğlu, D. (2012). Bir Meslek İki Farklı Profil: Türkiye'de Endsütriyel Tasarımı Eğitimindeki Farklı Öğrenci Kabul Sistemleri ve Yansımaları. ITU Graduate School of Science Engineering and Technology, Unpublished Master Thesis.

Forés, B., and Camisón, C. (2016). "Does Incremental and Radical Innovation Performance Depend on Different Types of Knowledge Accumulation Capabilities and Organizational Size?". Journal of Business Research, 69(2), 831-848.

Frith, C., and Law, J. (1995). "Cognitive And Physiological Processes Underlying Drawing Skills”. Leonardo, 203-205.

Franke, N., Von Hippel, E., and Schreier, M. (2006). “Finding Commercially Attractive User Innovations: A Test of Lead User Theory". Journal of Product Innovation Management, 23(4), 301-315.

Gibbons, H. 2007. Teaching Dance: The Spectrum of Styles. AuthorHouse, Indiana.

Grossman, M. (1970). "Perceptual style, creativity, and various drawing abilities." Studies in Art Education, 11(2), 51-54.

Ho, C. H., Eastman, C., \& Catrambone, R. (2006). “An investigation of 2D and 3D spatial and mathematical abilities". Design Studies, 27(4), 505-524.

Holmes, J., \& Adams, J. W. (2006). “Working Memory and Children's Mathematical Skills: Implications for Mathematical Development and Mathematics Curricula". Educational Psychology, 26(3), 339-366.

Jansson, D. G., and Smith, S. M. (1991). “Design Fixation”. Design Studies, 12(1), 3-11.

Küçükerman, Ö. (2006). “1971 Yılında Türkiye’de ilk Kez Güzel Sanatlar Akademisi ile Başlatılan Endüstri Tasarımı Eğitiminin 37 Yıllık 'SEYiR DEFTERi'”. Tasarım + Kuram, 3 (5), $1-27$
Linsey, J. S., Tseng, I., Fu, K., Cagan, J., Wood, K. L., and Schunn, C. (2010). "A Study of Design Fixation, Its Mitigation and Perception in Engineering Design Faculty". Journal of Mechanical Design, 132(4), 041003.

Lesh, R. (2000). What Mathematical Abilities Are Most Needed for Success Beyond School in a Technology Based Age of Information?. In: Proceedings of the International Conference on Technology in Mathematics Education (Auckland, NZ, December 11-14, 2000).

Nelson, P. L., Martin, S. S., and Baldwin, V. G. (1998). "Drawing Skills and Science Concepts in Young Children: A Study of Relationships”. Studies İ Art Education, 39(3), 262-269.

Norman, D. A., and Verganti, R. (2014). "Incremental and Radical Innovation: Design Research vs. Technology and Meaning Change". Design Issues, 30(1), 78-96.

Obal, M., Kannan Narasimhan, R., and Ko, G. (2016). "Whom Should We Talk To? Investigating the Varying Roles of Internal and External Relationship Quality on Radical and Incremental Innovation Performance". Journal of Product Innovation Management, 33(S1), 136-147.

Perks, H., Cooper, R., \& Jones, C. (2005). “Characterizing the role of design in new product development: An empirically derived taxonomy”. Journal of Product Innovation Management, 22(2), 111-127.

Purcell, A. T., Williams, P., Gero, J. S., and Colbron, B. (1993). "Fixation effects: Do they exist in design problem solving?". Environment and Planning B: Planning and Design, 20(3), 333-345.

Resnick, L. (2001). Making America Smarter: The Real Goal of School Reform. In Costa, (Ed) Developing Minds: A Resource Book for Teaching Thinking, VA: Association for Supervision and Curriculum Development

Reuhkala, M. (2001). "Mathematical Skills in Ninth-Graders: Relationship With Visuo-Spatial Abilities and Working Memory”. Educational Psychology, 21(4), 387-399.

Schoenfeld, A. H. (1992). Learning to Think Mathematically: Problem Solving, Metacognition and Sense Making in Mathemetics, In: D. Grouws (Ed.) Handbook of Research on Mathematics Teaching and Learning, New York : Macmillan.

Smith, S. M., Linsey, J. S., and Kerne, A. (2011). "Using Evolved Analogies to Overcome Creative Design Fixation". In Design Creativity 2010 (pp. 35-39). London: Springer.

Urban, G. L., and Von Hippel, E. (1988). "Lead User Analyses for the Development of New Industrial Products". Management Science, 34(5), 569-582.

Verganti, R. (2008). Design, Meanings, and Radical Innovation: "A Metamodel and a Research Agenda". Journal of Product Innovation Management, 25(5), 436-456.

Verganti, R. (2009). Design-Driven Innovation: Changing the Rules of Competition By Radically Innovating What Things Mean. Harvard Business Press. 
Verganti, R. (2011). “Designing Breakthrough Products”. Harvard Business Review, 89(10), 114-120.

Verganti, R., and Öberg, Å. (2013). "Interpreting and Envisioning-A Hermeneutic Framework to Look at Radical Innovation of Meanings". Industrial Marketing Management, 42(1), 86-95.

Viswanathan, V., and Linsey, J. (2012). "A Study on the Role of Expertise in Design Fixation and Its Mitigation". ASME Paper No. DETC2012-71155.

Won, P. H. (2001). "The comparison between visual thinking using computer and conventional media in the concept generation stages of design". Automation in Construction, 10(3), 319-325.

Woodman, R. W., Sawyer, J. E., and Griffin, R. W. (1993). "Toward a Theory of Organizational Creativity". Academy of Management Review, 18(2), 293-321.

\section{Internet Sources}

ITU. (2018). End. Ürünleri Tasarımı (\%100 İngilizce) Ders Planı. http://www.sis.itu.edu.tr/tr/dersplan/plan/EUTE/201110 .html

METU. (2017). Department of Industrial Design. https://catalog. metu.edu.tr/program.php?fac_prog=125

MU. (2012). ENDÜSTRİ ÜRÜNLERİ TASARIMI BÖLÜMÜ ENDÜSTRİ ÜRÜNLERI TASARIMI ANASANAT DALI 2012-2013 EĞİTIM ÖĞRETIMM YILI BAHAR DÖNEMİ. http://dosya.marmara.edu.tr/ gsf/eut/Ders_Pro.2012-13_bahar.pdf

MU. (2017). Marmara Üniversitesi Güzel Sanatlar Fakültesi 20172018 Özel Yetenek Giriş Sinavları Kılavuzu. http://dosya. marmara.edu.tr/gsf/YIL_2017/duyurular/2017-2018_OZEL_ YETENEK_GIRIS_SINAVLARI_KILAVUZU.pdf

MSFAU. (2017-a). Mimar Sinan Güzel Sanatlar Üniversitesi 2017/2018 Eğitim-Öğretim Yılı Güzel Sanatlar Fakültesi Yetenek Sinavları Kılavuzu. http://yeteneksinavi.msgsu.edu. tr/Files/GYS_kilavuz.pdf

MSFAU. (2017-b). 2017-2018 Ders Planı. http://www.msgsu.edu. tr/tr-TR/lisans/887/Page.aspx

ÖSYM. (2017-a). LYS Soru Kitapçıkları ve Cevap Anahtarları. http://www.osym.gov.tr/TR,13193/2017---lys-sorukitapciklari-ve-cevap-anahtarlari.html

ÖSYM. (2017-b). 2017 Öğrenci Seçme ve Yerleştirme Sistemi (ÖSYS) Kılavuzu. https://dokuman.osym.gov.tr/pdfdokuman/2017/ OSYS/LYS/KILAVUZ_18042017.pdf

ÖSYM. (2018). TABLO-4 Merkezi Yerleştirme İle Öğrenci Alan Yükseköğretim Lisans Programları. https://dokuman.osym. gov.tr/pdfdokuman/2017/OSYS/YER/Tablo-4_12082017. pdf 